\title{
Remote, informal, and ephemeral communities for testing technologies
}

\section{Silvia Vicente-Oliva}

\section{Ángel Martínez-Sánchez}

\section{Abstract}

Nowadays our world is more connected than ever, and as a consequence, truly isolated places on planet Earth are very rare. This is perhaps because humankind has always travelled beyond frontiers to explore faraway places, and also because technology enables the application of science and skills, and the extraction or collection of resources from new regions.

Some technologies can change the current view and future expectations of our societies, and the way that people interact within their immediate environment. Remote communities offer the opportunity to research the next step in the evolution of technologies. Through the study of narratives, this paper investigates the remote, informal, and ephemeral communities of practices (RIE-CoP) that undertake the brief use of some technologies. The use of additive manufacturing technologies for improvised repairs, rapid tooling, the study of potential efficiency energetic measures, and previous tests in the Spanish Antarctic Base provide short-term benefits such as reducing emissions and logistics costs, and making life more sustainable on the frozen continent. Furthermore, these technology tests offer action-based research about the management and future of RIE-CoP under extreme conditions across four Antarctic missions (from December 2015 to March 2019). The experiences provide narrative foresight for the future RIE-CoP, and the results are valuable in sectors such as military and humanitarian assistance, construction, and space missions. 
Keywords: additive manufacturing; community of practices; efficiency energetic; testing technologies; future narratives

\section{Introduction}

The modern realities around physical distances and technological evolution make the integration of new technologies quicker and easier in our complex and high-tech world. However, there are indeed places on Earth where people can live isolated from other human groups, either for economic, ideological or health reasons. These rare spaces offer ground for testing the utility of new technologies, and for confronting cognitive and organizational barriers. Some communities in remote places are permanent, such as native tribes, but others are temporary, like research missions in Antarctica.

There are communities that are highly organized, while others are mostly ruled by informal politics (Bammer, 2018). Whatever their origin and nature may be, however, their success is related to shared knowledge and trust among members (Wenger \& Snyder, 2000; Yang, 2009) since informal groups are less reluctant about exchanging information (Li et al., 2009). The Community of Practices (CoP) is therefore fertile ground for the later spread of technologies into other ecosystems, because its members can learn about the benefits and limitations of these new technologies. Moreover, if the rules of the organizations to which they belong enable the practical integration of technologies into long-term planning, it could enhance the ongoing foresight engagement (Peter \& Jarratt, 2015).

The literature offers many definitions of a CoP that are suitable for describing the key features that could characterise the groups of people in a network, for example: sharing knowledge, values, and visions for generating new knowledge, and co-operating over increasing capabilities, fostering innovation, etc. (Pór \& Bekkum, 2004; Stevenson, 2002). Although subjects related to remote communities are commonly discussed in Sociology, Environmental Sciences, Energy and Electrical Engineering, and even Medicine, managerial issues are frequently neglected, with the exception of some studies focusing on the fields of Operations Research and Entrepreneurship (e.g. Burnett \& Danson, 2017; Obydenkova et al., 2018). Our study focuses on a particular CoP that is composed of civilian researchers 
and military staff on the Antarctic base (throughout the last four missions, each of four months, since 2015-2016), and their remote support.

This paper collects the experiences and memories of some RIE-CoPs which shaped the ability of their members to imagine non-existent events or even simulate future directions (Schacter, Addis, \& Buckner, 2007) in the use of additive manufacturing and efficient energy technologies. Both experiences are connected to Antarctica, and provide narratives from an environment with limited resources to support people, as would also be the case for natural disasters or space missions. Narratives enable future thinking about subjects ranging from new technologies to potential uses of RIE-CoPs, and allow us to imagine multiple alternative visions of the future (Miller, O'Leary, Graffy, Stechel, \& Dirks, 2015; Milojević \& Inayatullah, 2015). These narratives likewise suggest "futures" because they are "depictions of possibilities yet to be realised, as are 'designs' [...] that includes product prototypes" (Raven \& Elahi, 2015, p. 50). In this study, the intersection of future thinking and imagined futures afford future narratives based on users' interactions and social groups that could develop more adaptive futures for later experiences on the Antarctic continent or for another RIE-CoPs.

There are several key issues around the operation of this type of CoP, but perhaps the most critical ones are those related to the management of social groups and the interactions between members due to the "dense" relationships of mutuality that arise inside these CoPs (Lindkvist, 2005). Remote places need robust technologies because technical support is limited, and CoPs that create and use new forms of knowledge can be focused on other tasks that are more relevant for their survival, or are directly related to every position of each member in the group. The CoPs examined in our study comprise a heterogeneous mix of individuals with specialized skills and goals related to their missions that showed that CoPs can be a suitable way of learning, e.g. for the insertion of new technologies. The Antarctic experiences show how the preconceived notions of the individual members of the CoP clashed with the realities of the environment (Maturana \& Varela, 1994). 
The testing of emerging technologies in the Spanish Antarctic Base provides information about the technologies themselves, and also about their future impact and how to deal with those issues, as these CoPs are composed of personnel with different levels of responsibility who are committed to the mission for a very limited period of time. This paper therefore analyses some Antarctic experiences because they are a source of organizational information for any future remote, informal, and ephemeral community of practices (RIE-CoP). The CoPs studied are usually established to carry out scientific and technological tests or research projects in environments with limited resources and very strict deadlines. Therefore, the members of such CoPs need "learning by doing" and "knowledge sharing" abilities throughout the development of their scientific and technological activities. These abilities could determine the formation of a group of interest about a topic.

Other approaches and methods may be also be suitable for explaining the systems, actors and agents more deeply to conclude with a metaphor like the Causal Layered Analysis (Hampson, 2010; Inayatullah, 1998, 2004, 2010; Milojević \& Inayatullah, 2015). The analysis could also build some scenarios for exploring or anticipating this type of CoP (e.g. Bradfield, Wright, Burt, Cairns, \& Van Der Heijden, 2005), or a vision for this community ecosystem that merges the distributed knowledge and design common in emerging technologies (Ramos, 2017).

Our study contributes to the literature in several ways. Firstly, it reveals some results and challenges from RIE-CoPs that may be useful for management, especially around managing innovation and integrating technologies in remote places in a very short period of time. The experiences from Antarctica show the synergies between "doing" and "learning" in an informal way. Secondly, our study offers insights about the future development of RIE-CoPs in extreme contexts, suggesting possible improvements if members could train together before the mission, increasing the sense of belonging to the community, and maintaining fruitful relationships to continue working in the same spirit of fellowship as they did in Antarctica. Finally, our research contributes to the concept of cosmo-localism (Ramos, 2017) by considering its application in a new and different context. Some of the main challenges faced by humankind in our near future, such as global 
warming, global terrorism, viral pandemics, etc., are going to require perhaps an increasing spread of RIE-CoPs around the globe, not only to collect information but also to apply in situ technologies and management frameworks that offer effective responses to challenges such as catastrophes or humanitarian crises.

The article is structured in the following way. The next section describes the experiences of some RIE-CoPs in Antarctica by analysing user interactions, the social groups involved and their impact beyond Antarctica. We then explain the implications of our results from a theoretical and practical perspective. Finally, we end with a discussion of potential directions for the future of this kind of CoP and our concluding thoughts.

\section{CoPs in Antarctica}

The remote, informal, and ephemeral CoPs studied are based on Deception Island (Antarctica), which is situated in the archipelago of the South Shetland Islands and administered under the Antarctic Treaty System. Today, Argentina and Spain have ground research bases there. The Spanish Army began to operate the Antarctic Base in 1988, with tasks distributed between Army staff and the Operational Logistic Force. The logistic support serves the Spanish Ministry of Education and Science and the Spanish Polar Committee. The aim of these missions is to provide logistic support to scientific research, and also to carry out research projects of interest to the Army in the fields of transmissions, environment, health, clothing and camping equipment, and testing new technologies. The scientific staff of several projects proposed a rigorous work plan for short visits by civilian researchers (from 2 weeks to 4 months), with military personnel support throughout the whole mission (about 4 months).

Our study covers two main research fields: additive manufacturing and energy efficiency. Regarding additive manufacturing technologies, the first research project for an Antarctic mission was started in the year 2015; these technologies are considered to be game-changing technologies for future security and defence issues in the international context (Brimley, Fitzgerald, \& Sayler, 2013; Duchêne et al., 2016; Horowitz, 2014). Their utility is well known, and their future development is discussed in several studies (Busachi 
et al., 2018; Rayna, Striukova, \& Darlington, 2015). Additive manufacturing technologies can reduce raw material consumption by up to $75 \%$, contribute to containment operative costs, increase the effectiveness of the mission without supply routes, and also have environmental benefits (Baumers, Dickens, Tuck, \& Hague, 2015; Hopkinson, Hague, \& Dickens, 2006; Metal AM, 2013; Zhai, Lados, \& LaGoy, 2014). We studied four consecutive missions that used remote assistance to design non-critical spare parts, and some plastic tools for researchers that were not included in the cargo manifest. Everyone on the Spanish Base was involved in these projects every year, with the remote support of an engineering design group of four people based in Zaragoza (Spain) via online communications (Table 1). Military personnel were interviewed before and after each mission.

Regarding energy efficiency, the focus in Antarctica was on energy consumption in buildings. The global contribution by buildings towards energy consumption has gradually increased in developed countries; for instance, Pérez-Lombard, Ortiz, \& Pout (2008) estimated consumption to be between $20 \%$ and $40 \%$. The integration of new technologies and procedures for energy issues is considered a transversal capability in Europe (European Defence Agency, 2012). There are some analyses of the field that have shown the relevance of these technologies in international operations with supply limitations, e.g. McManus (2016) in Mali, and Rodríguez Soria (2017) in Lebanon. The results are lower operational costs, more effective missions because it is not necessary to redirect resources to assure logistic chains, and lower environmental emissions and logistic footprints. At the Antarctic base, a project carried out in the mission of 2018-2019 involved, principally, military personnel. The group of researchers was composed of two people, with one extra engineer based on the ground for one month. Table 1 describes the characteristics of the CoP involved in all these research projects. The experience of the CoP members was collected before, during and after each mission.

Table 1. Description of the examined CoPs

\begin{tabular}{|c|l|l|l|}
\hline CoP & \multicolumn{1}{|c|}{ Description } & Constitutive aspects & \multicolumn{1}{c|}{ Sources of evidence } \\
\hline CoP A & $\begin{array}{l}\text { CoP A (4 from December } \\
2015 \text { to March 2019) was } \\
\text { formed by military and }\end{array}$ & $\begin{array}{l}\text { Self-emerging } \\
\text { Self-organized }\end{array}$ & 1 workshop before the first mission \\
\hline
\end{tabular}




\begin{tabular}{|c|l|l|l|}
\hline CoP & \multicolumn{1}{|c|}{ Description } & Constitutive aspects & \multicolumn{1}{c|}{ Sources of evidence } \\
\hline & $\begin{array}{l}\text { civilian personnel with early } \\
\text { user' experience in additive } \\
\text { manufacturing. Regular } \\
\text { communication was } \\
\text { established by email and } \\
\text { instant messaging. }\end{array}$ & $\begin{array}{l}\text { Exchange via online } \\
\text { communication }\end{array}$ & $\begin{array}{l}10 \text { semi-structured interviews after } \\
\text { the mission with informal community } \\
\text { leaders and core group members } \\
1 \text { workshop after the first mission }\end{array}$ \\
\hline CoP B & $\begin{array}{l}\text { Communications online throughout } \\
\text { four missions } \\
\text { March 2019) was formed by } \\
\text { military and civilian } \\
\text { personnel whose fields of } \\
\text { expertise were energy } \\
\text { saving and construction } \\
\text { engineering. }\end{array}$ & $\begin{array}{l}\text { Self-emerging } \\
\text { Self-organized } \\
\text { Exchange via offline } \\
\text { communication }\end{array}$ & $\begin{array}{l}\text { Pojeports (2015 and 2016) } \\
\text { community members (a preview } \\
\text { analysis) } \\
\text { Project Report (2018) }\end{array}$ \\
\hline
\end{tabular}

These CoPs were self-emerging and self-organized since nobody designed their creation before the mission. The Antarctic Base "Gabriel de Castilla" has a robust communication system; therefore, contact with Spain was instantaneous. Originally, the projects with the Antarctic base and the logistic division were conceived for technical testing. However, in the planning phase, the expectations and thoughts of the participants were put together, and the adoption of new technologies for their work and lives, as well as for their community (Lave \& Wenger, 1991) was taken as read. The first CoP was created by makers, users, and visionaries because all the participants contributed with skills and knowledge (Liedtka, 1999) to allow the missions to deal with technological change in advanced ways. This is also an example of user-driven (von Hippel, 2015) and time-pressure innovation that offers reflections for the future of RIE-CoPs.

The Antarctic Mission has a single goal: research. The researchers who stay at the Base define a research plan before being selected, and then try to accomplish it during their stay in Antarctica. Their schedule means that other tasks that are not related to their research projects are difficult to accommodate, at least in theory. The reality is that researchers are curious individuals with an interest to explore beyond their own scientific worlds; therefore, a research visit in a place without their daily distractions and 
interruptions produces a sense of freedom that boosts interactions with other researchers and brings them together in many common areas of interest.

We have analysed the experiences of these CoPs in Antarctica with an empirical focus on how people act in organizational contexts, and a theoretical focus on understanding relationships between people's actions and the structures of organizational life. Cognitive and technical perspectives (Gavetti, 2012) are combined in the analysis. Moreover, our study (Figure 1) is performed at every level, encompassing the recursive interaction between people, technologies, and social interaction for innovation (Orlikowski, 2000; Wilson \& Doz, 2011) in their context of knowledge. The next three subsections describe our main findings.

Figure 1. Dimensions of the social construction of innovation in remote, informal, and ephemeral CoPs

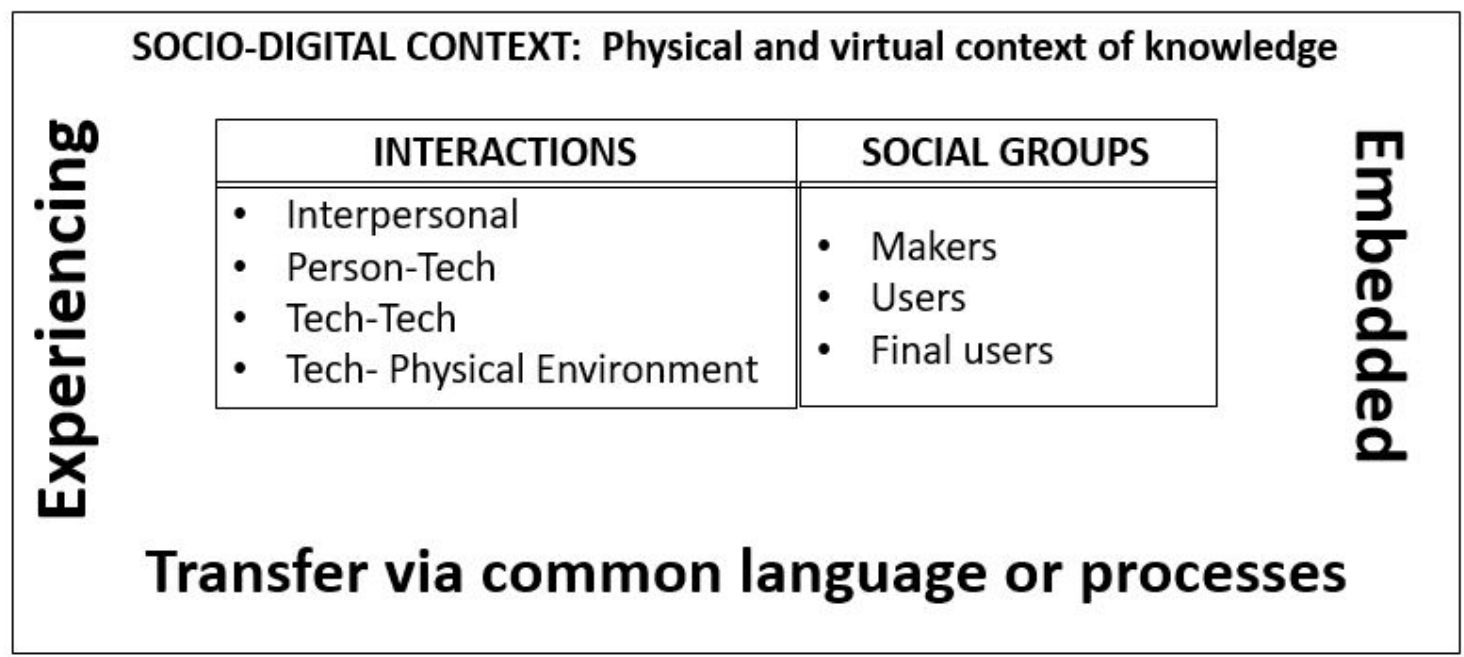

\subsection{User interactions}

Specialist users in the Antarctic CoP are researchers from different areas of knowledge: biologists, engineers, geographers, bromatologists, etc., and they can also be makers and final users if they are involved in the conception, design, or testing of any technology. We start with the first technology: additive manufacturing. The initial 
producers of 3D printing projects were military personnel (with remote assistance for transferring the design into the machine language), and their efforts were directed towards spare parts, rapid tooling, and design improvement, among other things. For instance, Figure 2 shows drawings of plugs of different sizes and an application sheet of a scissor closure for diving.

Figure 2. Examples of co-designing with users (free petitions of users and standardized format for military personnel)
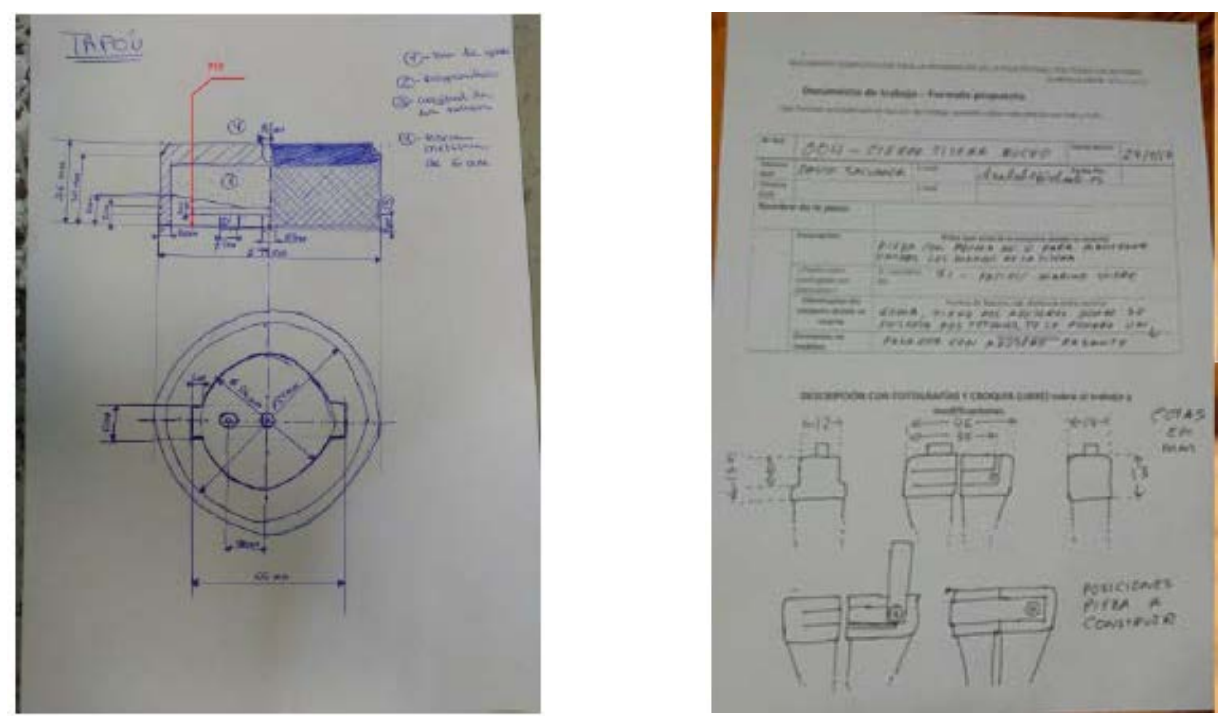

The scientific personnel who understood the potential uses of the $3 \mathrm{D}$ printer proposed a better design for their scientific equipment or tools. For instance, a data logger used to register the activity of the penguins in the sea was redesigned and tested with improved symmetry which makes their placement on the animal easier. Other uses of additive manufacturing were more personal or representative, for instance a commemorative coin for every member of the mission. These examples indicate that crossfunctional collaboration is vital, including multiple stakeholders outside the organization. Excerpt from a conversation between two CoP members:

A researcher sat down on the bench for dinner, shifted a bottle to look forward. "We are having problems with the penguin-tracking device, and lost two of them today. These are expensive and limited, so we cannot lose a new one tomorrow". 
"Ummm... What if you could test a way to place it on animal's with a degradable piece of plastic, would that help?" enquired the Sergeant in charge of the 3D printer.

"It could help ... But we are also considering the possibility that the design of the device is not good enough for the penguin aerodynamics ... Let me see, could we change the shape maintaining the necessary box to include the electronics?" asked the scientist engrossed in her thoughts.

"Yeah... If you can draw it, we can make it". ${ }^{1}$

The informal method of designing (with a drawing) and communicating with the designers encouraged the members of the CoP to consider the 3D printer possibilities in order to increase their own capabilities. The motivation to use and co-create in a place with very limited logistics thus makes common synergies possible; collaboration encourages results from innovation projects (Vicente-Oliva, Martínez-Sánchez, \& Berges-Muro, 2016). The physical context of knowledge is more important than the virtual, because communications outside the base were made for supporting the design of the pieces needed on the Base. In cases where the users or final users learned to make the product, technical support was not required. In future, 3D scanners that are more precise or which could even redesign the structure of the pieces in order to increase their resistance would require less material (PolyLactic Acid or PLA was used for environmental reasons) and decreasing machine times, etc. This CoP could work isolated with a PLA stock for the next few years.

People on the Spanish Antarctic base experience a low level of comfort in the living module during their stay. Efficiency characterization of the base and the study of its impact in permafrost were the first tasks undertaken. Residents of the module did not get involved until solutions were established, such as levelling the site floor level, a new panoramic window, etc. In February 2019, the 28 residents also envisaged zero dependence on fossil

\footnotetext{
${ }^{1}$ This sentence is also included in a remarkable work by Kietzmann, Pitt, \& Berthon (2015) p. 210.
} 
fuels. This is a shared vision that allowed for the co-design of a new project idea for the following years: the "Smart Green Base". Their plans combine ideas for using wind (although there are up to three days a week without wind on the island), solar panels inserted into the wall structure, a fuel cell with methanol, etc. This CoP could work isolated for a long time without any external support if they have enough building materials.

As a preliminary conclusion, we can state that interactions in these informal and ephemeral CoPs were sufficient to achieve innovations that improved their research and optimized their stay. The remote situation of these researchers was well addressed through the communications systems. This result suggests that innovation in the RIE-CoP on Antarctica was mostly user-driven and conditioned by time pressures. This means that the management of these CoPs would benefit from paying great attention to interpersonal communication, either online or onsite, as well as to the time commitments of the CoP members.

\subsection{Social groups}

The second element of our framework for analysing Antarctic CoPs (Figure 1) is the social groups of makers and users. In Antarctica, the members of RIE-CoP are users of any technology that is needed to carry out their missions and survive. Nevertheless, at the same time they also become makers whenever they need to develop something new or complement an existing technology or equipment. There are several social groups at the Antarctic base and they are very well differentiated: military vs civilian; researchers vs support staff (for facilities, kitchen, etc.); and finally other visitors (for instance, the then Spanish Minister of Science, Innovation and Universities Pedro Duque who visited the island for the inauguration of the new facilities in 2019). Some of them make only short research stays whereas others stay throughout the whole mission.

The main differences observed by this research among social groups inside the Antarctic base were their technical capacities and their communication skills to pass their visions onto technicians. After dinner, informal talks allowed them to share experiences, ideas and expectations in a straightforward way. Although Spanish was the common language, the scientific and technological backgrounds were different for every member of 
the CoP. They therefore had to adapt to each other's vocabularies, which created a transfer of knowledge and allowed them to create drawings for the 3D printing, or explaining the measurements of the life-container point-by-point for energetic efficiency.

We begin our analysis in CoP A which focused on the use of 3D printers, and afterwards in CoP B which only focused on energy efficiency projects. Firstly, the main challenge faced by CoP A was to create 3D designs in the imagination (imagination meaning the ability to form mental images of anything that is not present or may not even exist): if you cannot imagine it, you cannot make it. Members of the first expedition (CoP A) to Antarctica were rethinking the past and telling stories like this:

"We were in a town with civilians in 2006 and a piece of the water tank pump was broken. The replacement came after two weeks, and among all our spare parts there was nothing useful. A 3D printer would have enabled a solution in a few hours from designing and manufacturing to testing. It might not have lasted as long as the original, but should have not required the water to have been rationed as much as it was during these hard days for the people."

Regarding CoP B, its research projects also involved the study of wildlife behaviour in the air, on the ground, and in the deep sea, as well as analysing quality of air, variations in temperatures, etc. The damage that our planet is suffering due to human activity is especially noticeable in places like Antarctica where wildlife is more dominant than human activity. The researchers from CoP B are deeply knowledgeable about the negative effects of climatic change in their area of expertise. Reduction of the human footprint in every natural space is required to protect the Earth, which means reconsidering the present by embracing every technological resource for conceptualising a better future with a healthy planet. As a consequence, CoP B, which was in charge of energy efficiency projects, was aware of the implications of their work and also the need to imagine new scenarios. CoP B was also more focussed on human impact, and was actively looking for alternatives to fossil fuels. The researchers of COP B collaborated across different disciplines and this cooperation has shown that the integration of operative practices is possible through interpersonal interactions. 
"If this base could be self-contained, it would demonstrate to the rest of the world that living in spaces with limited resources is a way to live more sensitively towards nature".

CoPs are formed by social groups with ethical, political and epistemological values that produce a configuration profile, and the epistemological ones greatly influence the production of the interdisciplinary knowledge (their principles and fundamentals) that CoPs need. It would be fruitful for the systematic knowledge of the relationships between technology, the natural environment and social practices to be harnessed by universities, firms, government agencies, and foundations that support research in Antarctic CoPs. This would avoid the configuration of these CoPs sometimes being subordinated to the shortterm benefits that the research projects obtain, which reinforces the problems associated with time pressures explained in the previous subsection:

"This project (about air quality measurement) is really interesting, and my team needs to find a sponsor for the next three years. I am sure that additive manufacturing is a very promising technology but for the next two weeks my time is committed to adjusting the measure sensors and locating the in the designed places".

Following our description of the CoPs, we can detail their social groups. Those in CoP A were heterogeneous because some members were only makers, others were both makers and users, and lastly there were also just final users. CoP B only had final users but social groups in A and B both needed imagination abilities and a common vision for the future. However, the challenge to manage social groups is perhaps more difficult within CoP A than within CoP B because makers and users have mutual interdependences whereas final users do not rely on onsite makers. The social groups studied had ephemeral relationships but they decided to collaborate at their own risk and contributed in their own capacity. They reflected upon their experiences at the time and found some ways to improve their stay (research results, comfort, dissemination of results, etc.), and imagine future developments of the tested technologies for making our world a better place. 
The CoPs studied do not only provide information that has technical impact, but also information with a strategic impact for creating and adapting the new integration of technologies in the future. However, the success of the projects carried out in Antarctica depended on the sensitivity of the CoP, because no one participated in the projects on a mandatory basis, not even military technicians, since research tasks were not included in their orders.

The Antarctic missions periodically attract scientific personnel who know the difficulties of doing research in a restricted place and period of time. In this research context, RIE-CoPs operated within objectives fixed not only by individuals (scientific personnel), but also by their umbrella organizations and sponsors (Spanish Army, Research and Technology Organizations, etc.). Yet the participants found ways to build their own reality using new technologies with the support of members both within the base and outside, thanks to good communications systems. Actions taken by individuals and cooperation over processes and tools create an innovative environment that allowed them to respond to changes by following a plan. In particular, these CoPs encouraged innovation because the problems are complex, solutions are still unknown, and relationships among makers, users, and final users are informal with no clearly defined scope.

\subsection{Outside influence}

The impact of the CoP outputs reach beyond the Antarctic base. The testing of technologies in Antarctica was set up as a down-top innovation with a small budget and low expectations about the utility of the technologies in an extreme scenario. However, the expectations of the civilian and military personnel were high, as was their commitment to the goals. Their vision made new initiatives possible, such as special sessions designed to promote the integration of additive manufacturing in the Army, Navy, and Air Force. Among other things, the experience in the Antarctic Base led to a conference in Madrid to share experiences of defence materials and technologies used by military units, universities, and firms (Spanish Ministry of Defence, 2017). Since the initial project on 3D printing, other initiatives have been carried out in Europe around this technology, of which the proof of 
concept for the European Defence Agency in a Spanish manoeuvre camp is the most wellknown (European Defence Agency, 2017). The implications of these spill-over effects will be discussed in the next section.

\section{Study contributions}

The study of the RIE-CoPs in Antarctica offers some insights that have theoretical implications but can also be taken as a starting point to consider the future of these CoP. This section covers the theoretical contributions of our research and the next section describes our vision of a potential future. To analyse the theoretical contributions, we draw on each previous subsection (user interactions, social groups and outside influence).

\subsection{User interactions}

Firstly, the analysis of user interactions (subsection 2.1) suggests that innovation in a RIE-CoP is mostly user-driven and conditioned by time pressures. Necessity is indeed the mother of invention. These CoPs are action-driven organizations because they have more constraints on material resources and face more time pressures than other organizations, which forces them to be more efficient in finding solutions to problems and make the most of the limited resources available. They are not an adequate context for traditional, topdown, control-oriented management of innovation and change (Ross, 2010; Warner \& Wäger, 2019). Instead, there is a greater need for self-organizing, user-driven and timeresponsive innovation.

Learning by doing, and quickly - as fast as possible - is a core and essential goal in RIE-CoPs where speed may even mean survival. These CoPs are formed by individuals who interact in order to respond to changes by developing working items needed by (internal) customers. There are two types of interactions within social activity that coordinate the actions for mutual adaptation (Maturana \& Varela, 1994). In the first, the behaviour of scientific personnel directly shapes the behaviour of the support team (on-site assistance, and remote assistance); in the second, the technical group guides the scientific personnel who are supporting their activities. 
Innovation in a CoP focuses on what CoP members do (execution) rather than on what they are instructed to do (Pyrko, Dörfler, \& Eden, 2019). Innovation processes generally aim to turn product visions into reality as soon as possible, rather than by developing voluminous plans and schedules. When a CoP is ephemeral and remote, its need to learn from what their members do is greater, and it has to bring positive solutions to meet strict deadlines more quickly than would otherwise occur. Innovation should also engage the entire CoP, tapping into the very best ideas from people serving in every role of the CoP.

Human society is under asymmetric crisis, environmental problems are affecting every life system, and political, social, cultural, and economic issues produce an open patchwork for people and nature. A world where many other worlds also have a place shapes the concept of a "pluriverse" (Escobar, 2018). Users inside CoP could configure a pluriverse through the communal forms of autonomy that their members have during their research stays, and the military team that supports them throughout the expedition.

\subsection{Social groups}

Subsection 2.2 has highlighted the role of interactions within social groups. Social groups are an important element in the theoretical model developed by Wenger (Wenger, 1998). The CoPs have particular characteristics but they still fulfil the prescribed features established by Wenger: domain, community and practice. Nevertheless, the special nature of the Antarctic CoPs means that not all Wenger's indicators have a place in these ephemeral communities. Indicators that do apply to our CoP are, for instance: mutual engagement for a very quick resolution of a problem; joint enterprise because it is important to know what others know, what they can do, and how they can contribute to activities; a shared repertoire of jargon and communication shortcuts for developing productive ideas.

Thus, members of a remote CoP should be in a position to share any kind of knowledge they have or may acquire during the CoP's existence. Otherwise, the limitations and obstacles to the transfer of knowledge could jeopardize the successful development 
and strict deadlines of the CoP's research projects. Consequently, the high need for learning and knowledge transfer in a CoP force its members to have a proactive attitude to innovation and to manage it within the context of limited resources and time pressures.

Brown and Duguid (1991) argue that significant learning and innovation is generated by informal CoP carrying out both officially-sanctioned and non-canonical practices (unorthodox ways of developing their tasks, or under unrecognized rules). RIECoPs can therefore offer a dialogue around learning, innovation, and change as a reflexive social process (Fuller \& Warren, 2006) because learning-by-doing is a temporary process which not only needs interactions among workers, users, learners and innovators, but also external communications between social groups. Collaboration between civilians and researchers incorporated in the Armed Forces can influence the rate and direction of scientific activity (Colatat, 2015). A study by Kreutzmann, Koller, Andresen, \& Schulte (2016), which analysed the process of knowledge creation and CoPs within the German Federal Armed Forces, concluded that a CoP follows Nonaka's acknowledged SECI-process (Krogh, Nonaka, \& Aben, 2001), and that it is a flexible, informal method for the integration of external expertise inside the organization, even considering its hierarchical aspects and its large size. Informal groups exchange information easily (Li et al., 2009). Therefore, these communities share their knowledge freely and without formal tools, such as during their daily tasks, after dinner, etc.

\subsection{Outside influence}

Thirdly, there may also be some theoretical contributions about the importance of CoPs in Antarctica that influence the development and dissemination of knowledge activities in other places, as well as on the Anthropocene.

RIE-CoPs could be nodes of a decentralized system of knowledge creation and absorption capacity. Ramos (2017) developed the concept of cosmo-localism, which "...takes place when easily accessible designs are paired with localized and distributed production capabilities using new breakthrough technologies that facilitate local manufacture/production" (page 65). He gives examples of cosmo-localism in industrial 
settings that require the development of centralized production facilities with decentralized global knowledge.

Our approach expands the paradigm developed by Ramos (2017) by stating that CoPs could not only be nodes of decentralized global knowledge but also decentralized and coordinated testing laboratories of new applications of known and experimental technologies. These types of CoP are usually the first line of defence, be it in natural disasters, security crises, any kind of 'black swan' events, or viral pandemics like Covid-19. This means that their knowledge development has to be instantly shared and continuously updated. That would be the essence of cosmo-localism of knowledge where no CoP could operate or even survive without interactions, i.e., inputs and outputs of knowledge from other CoP and within their own.

However interesting all the discussion in this section is from a theoretical point of view, we think that it is more important to extrapolate where we can to other organizations that share similar characteristics with the CoPs in Antarctica. The frozen continent is nowadays a laboratory of experiences but it is also a special frontier for humankind because it gives us the opportunity to solve conflicts in a global way. There is still so much to learn from that for the future, in the "praxis of living" (Maturana \& Varela, 1994).

Our study has found that CoPs in Antarctica may contribute to analysing how individuals develop and process knowledge in environments with limited resources and time constraints. Other ephemeral settings like film sets or extreme sports events also have constraints, but what makes Antarctica's CoPs different from those ephemeral settings is their quest for knowledge ${ }^{2}$. Learning quickly and sharing knowledge informally requires not

2 Most ephemeral organizations have temporary actors as well as a temporary structure which, to be effective, tend to "rely on complementary permanent organizational or interorganizational structures" (Sydow, 2017, p. 199). Regarding Antarctica, the Scientific Committee on Antarctic Research (SCAR) was created for initiating, developing and coordinating high quality international scientific research in the Antarctic region (including the Southern Ocean). SCAR provides scientific advice on issues of science and conservation affecting the region. In Spain, the Army began their activities to support scientific research in 1984. Every mission is different, however, and so are its scientific findings, so a longitudinal perspective, such as Roubelat et al., (2015) could propose for 
only interactions among users but also communications between many different groups, even outside the CoP's local territory.

Since the 1950s the influence of human activity on Earth and the anthropogenic factor have increased complexity in our planet's environments and created cascades of negative spill-over effects that affect us and our life-support systems (Lewis \& Maslin, 2015; Richardson \& Erdelen, 2018). Although "climate narratives rarely frame the consequences of climate change in terms of Future Thinking" (Coulter, Serrao-Neumann, \& Coiacetto, 2019 , p. 58), the experiences of the RIE-CoPs enable future-oriented reflection and exploration of the future use of technology (Szpunar, Spreng, \& Schacter, 2014) for increasing the habitability of Antarctica, or other very cold and dry climates, with minimum environmental pressures. Therefore, these Antarctic experiences also offer insights into the relationship between narratives, futures, and even future thinking in RIE-CoPs for exploring and altering our relationship with the places we inhabit now and in years to come.

\section{The future of remote, informal and ephemeral CoPs}

Generally, and according to reported experiences, the future of RIE-CoPs may be conditioned by a time-limited and user-driven innovation process, because individuals need to interact in order to respond to changes by developing working items to serve (internal) customers' needs. The style of interaction in these communities will be primarily interpersonal (individuals and interactions over processes and tools) because their ephemerality and distance from other human groups have more influence in their behaviour in informal relationships. Remote CoPs provide a context of smaller teams and stand-up meetings in comparison with other organizational contexts where people are forced to comply with the demands of external authorities and stakeholders. These CoPs need to learn from what their members do, and altruism is included in the social

scenarios in fashion design, cannot be developed. Among the most important goals of these activities for every country with a scientific base in Antarctica are researching, learning, and acquiring new knowledge. 
phenomenon (Maturana \& Varela, 1994, p. XIV) as it creates a better coexistence (new tools, more comfortable spaces, etc.). Therefore, innovation management techniques may be useful for RIE-CoPs because they would bring positive solutions more quickly than would otherwise occur. Experiences in RIE-CoPs could also lead to the creation of more sustainable social orders through new design practices. "Designs for the pluriverse become a tool for reimagining and reconstructing local worlds"(Escobar, 2018, p. 4). Future RIECoPs could support their own survival with a pluralistic approach more sensitive to the environment and society to which they are sent. Additionally, techniques for innovation usually engage the entire $\mathrm{CoP}$, tapping into the very best ideas from people serving in every role in the CoP, thus a culture of innovation in a deep and enduring way. This would make CoPs an extreme but very potent arena for testing innovation principles for their organization and viability. Future innovation in CoPs should be based on their stock of knowledge, their capacity for learning, and how to work with minimal reference to the past. A contingent framework for time-limited innovation designed by Wilson \& Doz (2011) defines the initial characteristics of knowledge into three categories: experiencing knowledge, or learning by doing; embedded knowledge, or seeing through different eyes; and transferring via a common language or process. These categories could be enacted through different initiatives in order to create and implement endeavours to absorb and integrate the knowledge inside the future CoPs dynamically.

The efficacy and efficiency of remote CoPs is critical due to the limited availability of time and resources. In future, management of a remote CoP should pay special attention to the selection of its members, as well as to their level of engagement during its mission. Based on the performance of the cases studied, remote CoPs would need to share knowledge even prior to their deployment. This means that members of a remote CoP should have to learn how to solve potential problems and difficulties before arriving on the ground. Since potential problems can be predicted, members of CoP can be trained in advance to solve them. This way, when facing real problems on the ground, they could identify and deal with them more quickly. Prior training in cooperative problem resolution would be more useful if completed by the whole CoP before its deployment, which may require some type of virtual reality shared among members located in different sites. This 
prior virtual relationship among members could contribute to the CoP's internal engagement, which is necessary to the accomplishment of the mission and even to people's survival. When in remote places, individuals need to connect and interact to carry out their duties; at the same time, they must have their own space for privacy and mental equilibrium. The future may come to the assistance of CoPs as new communication technologies are improving the virtual work of remote members, and will continue to do so. For instance, an Antarctic CoP could send a scan of broken machinery to a maintenance centre in Australia that could inspect the damage and prepare printable spare parts that in turn could be 3D printed in Antarctica.

Remote CoPs are not isolated. There is not only communication among the members, but also a large virtual community out there that provides personal, social and organizational environments for the researchers (Chen \& Hew, 2015). The CoPs that have been studied are in remote places where people share living space. According to Byrne's (2018) work, several factors contribute to the wellness of CoP members: social contact, contact with history and culture, contact with nature, accessibility and inclusiveness, connection to local place, special places, safe places, appropriate shelter, social support, places to express, robustness, and choices. However, the constraints of the mission will determine some of these factors for future CoPs. For instance, increasing the comfort of the visitors to the Antarctic base will be possible, but other factors, such as contact with the history and culture of the place, are hard or impossible to obtain (in this instance because Antarctica is uninhabited).

Future formal and informal CoPs could maintain the same goals as today, ceteris paribus. In terms of the cases discussed, there is no evidence that the military CoPs do not impact the effectiveness of the community at all if they share the belief that their duty serves the overall organizational purpose (Schulte, Andresen, \& Koller, 2020). The future for formal or informal CoPs depends on other characteristics of the individuals included, as well as the organizations that are involved, their management, and their ability to endure and replicate (Maturana \& Varela, 1994), barring black swans or wildcards. 
Temporary CoPs have their own strict deadlines. It is therefore difficult to conceptualise problems in future scenarios while the CoPs are still extant, if that existence is very ephemeral (Michel Godet \& Roubelat, 1996; Roubelat, Brassett, McAllum, Hoffmann, \& Kera, 2015). In the future, these ephemeral communities may hold together even after they have accomplished their mission if "passion, commitment, and identification with the group's expertise" (E. Wenger \& Snyder, 2000, p. 142) are maintained over time. For them, physical and technological relationships could respond to changes by following a plan drawn from the experience obtained during the short time that people were in the community as well as the knowledge gained throughout their lives. Therefore, the new technologies and knowledge used by RIE-CoPs might have relevance not only for their members, but also for the organizations or groups to which they belong. They will thereby boost the adoption of new organisational practices to enable the organizations to survive and grow.

In terms of their continued survival over time, remote CoPs will not be ephemeral, except in rare circumstances and wild card situations. Where that does occur, communities would have special systems and structures that we can only imagine. Informal CoPs might be a way to disseminate innovation and test ideas without pressure for short-term results; a way of collaborating when the CoP shows the right direction for future innovations. The current way of envisaging future scientific research in Antarctica still does not include a community of dreamers and thinkers, even though collective thinking is so important for the future (M. Godet, 2010). A CoP for solving future human challenges beyond our current limitations would be an invaluable organizational way of learning and creating the innovations of the future. How? Why not create a community of dreamers in Antarctica? Ramos (2017, p. 68) proposes the concept of a global knowledge laboratory that could be applied here. An increasing number of scientific personnel advocate supranational cooperation in order to resolve the human impact on every system on Earth, including the multidimensional challenges across environmental and demographic issues, pandemics, etc. (e.g. Sandler, 2004; Steffen et al., 2011; Walker et al., 2009). A community of dreamers in Antarctica could be devoted to undertaking global research projects with participation from several countries: a community still only imagined. This community would be a group 
of people who are not currently present and accessible, but who are connected through the imagination (Kanno \& Norton, 2003). In this way, the imagination can expand consciousness of time and space to create new conceptions of everything.

\section{Concluding thoughts}

There are several results from our study that lead to specific conclusions of interest for the creation and management of CoPs. Firstly, we have found that interactions among users (makers, users and final users) are very important in the operation and success of the CoP. Consequently, how and when the members of such CoPs are selected and trained should be carefully analysed. For instance, individuals who are strongly aligned with the CoP's values will be able to contribute more to its mission than others who do not truly share such values. It is also important for these long-term remote CoPs to work as a virtual community prior to deployment. The development of a virtual community is important because it enhances, for instance, engagement with the CoP, and facilitates a faster and more efficient resolution of problems. However, a virtual community is not enough in itself if its members do not receive the right amount and type of training, particularly teamwork training, virtual scenarios, fictional assignments, etc. Ephemerality does not mean that COPs lose the value they once had. Lessons learned could be analysed, and best practices could be used by other communities with pressure on development, or some other similar characteristics.

Secondly, in remote communities, innovation would probably be a practice to "save the day" rather than one that would achieve a new technological paradigm because in most cases, breakthroughs would be very interdisciplinary. In remote places, the community uses every skill, knowledge base, and opportunity to achieve its goals. In the CoPs studied, the feeling of belonging is irrelevant because the experience is ephemeral. This would not be the case under different conditions such as, among others, a wider remit, absence of communications with mother organizations, shortage of essential resources to guarantee life, etc. 
Thirdly, we have to take into account that participation in the CoPs studied was not mandatory, which limits the scope of a CoP's performance. This means that it becomes critical to find ways to attract members to the CoP. Free-riders are also a sensitive issue because some members could participate only for their own good without contributing to the joint effort. Even more seriously, there should be particular vigilance about any members who could jeopardize the work and organization of the CoP. This kind of situation in a remote environment could be very dangerous. We cannot forget that we are talking about informal participation with no legal obligations whatsoever. Nevertheless, there are quite a few CoPs whose members, although scientists from institutions, volunteer for their job but are strongly committed to their mission, like the teams of 'virus hunters' who search "bat caves" to predict the next pandemic.

Finally, RIE-CoPs may constitute another type of organization to which the concept of cosmo-localism may be applied. These CoPs need to share knowledge at close to zero cost, which facilitates the dissemination of innovation and the development of new technical solutions. One important consideration in the future of remote, informal, and ephemeral communities is the way that umbrella organizations design innovation as well as prior training for CoP members to work together. These CoPs need innovative designs that foster user-driven, even virtual, interactions and agile decision making. Furthermore, cosmo-localism could alleviate the strain on resources and the pressure of strict deadlines, which could expand the scope of research activities and the performance of these CoPs.

Our study design has limitations because the method relies on narratives from the frozen continent.

Our suggestions for RIE-CoPs offer a small contribution to the field, and may inspire new ways to increase cooperation in testing the next evolution of technologies. Future CoPs - as custodians of the knowledge that all kinds of previous experiences provided should be able to address known demands easily, while they provide the solutions to new challenges that technologies, their umbrella organizations, and humankind will need. 


\section{Acknowledgements}

These experiences was possible thanks to inspiring technical work and dedication of Marcos Pueo, Roberto Jiménez, Carlos Cajal, Miguel Ángel García, Joaquín Mur, and Beatriz Rodríguez Soria, members to the Antarctic Campaigns (XXX-XXXIV), the financial support of Centro Universitario de la Defensa Academia General Militar (CUD 2019-01), and the Government of Aragón (Group Reference CREVALOR: S42_17R). Thank you very much for this enriching experience. The authors would like to thank two anonymous referees for their valuable comments and suggestions. 


\section{References}

Bammer, G. (2018). Strengthening community operational research through exchange of tools and strategic alliances. European Journal of Operational Research, 268(3), 11681177. https://doi.org/10.1016/j.ejor.2017.09.041

Baumers, M., Dickens, P., Tuck, C., \& Hague, R. (2015). The cost of additive manufacturing: machine productivity, economies of scale and technology-push. Technological Forecasting and Social Change, 102, 193-201. https://doi.org/10.1016/j.techfore.2015.02.015

Beck, K., Beedle, M., van Bennekum, A., Cockburn, A., Cunningham, W., Fowks, M, Greening, J. (2001). The Manifesto for Agile Software Development. Retrieved July 15, 2019, from https://www.agilealliance.org/agile101/the-agile-manifesto/

Bradfield, R., Wright, G., Burt, G., Cairns, G., \& Van Der Heijden, K. (2005). The origins and evolution of scenario techniques in long range business planning. Futures, 37(8), 795812. https://doi.org/10.1016/j.futures.2005.01.003

Brimley, B. S., Fitzgerald, B., \& Sayler, K. (2013). Game Changers: Disruptive Technology and U.S. Defense Strategy.

Brown, J., \& Duguid, P. (1991). Organizational learning and communities-of-practice: toward a unified view of working, learning and innovation. Organizaion Science, 2(1), 40-57.

Burnett, K. A., \& Danson, M. (2017). Enterprise and entrepreneurship on islands and remote rural environments. International Journal of Entrepreneurship and Innovation, 18(1), 25-35. https://doi.org/10.1177/1465750316686237

Busachi, A., Erkoyuncu, J., Colegrove, P., Drake, R., Watts, C., Martina, F., ... Lockett, H. (2018). A System Approach for Modelling Additive Manufacturing in Defence Acquisition Programs. Procedia CIRP, 67(2012), 209-214. https://doi.org/10.1016/j.procir.2017.12.201

Byrne, J. (2018). Well-being and stronger communities. Australian Planner, 55(2), 58-64. https://doi.org/10.1080/07293682.2019.1602333 
Chen, Y., \& Hew, K. F. (2015). Knowledge Sharing in Virtual Distributed Environments: Main Motivators, Discrepancies of Findings and Suggestions for Future Research. International Journal of Information and Education Technology, 5(6), 466-471. https://doi.org/10.7763/ijiet.2015.v5.551

Colatat, P. (2015). An organizational perspective to funding science : Collaborator novelty at DARPA. Research Policy, 44(4), 874-887. https://doi.org/10.1016/j.respol.2015.01.005

Coulter, L., Serrao-Neumann, S., \& Coiacetto, E. (2019). Climate change adaptation narratives: Linking climate knowledge and future thinking. Futures, 111(May), 57-70. https://doi.org/10.1016/j.futures.2019.05.004

Duchêne, V., Padilla, P., Van der Velde, E., Wastyn, A., Nuñez, L., Knotter, S., ... Wepner, B. (2016). Identifying current and future application areas, existing industrial value chains and missing competences in the EU, in the area of additive manufacturing (3D printing). https://doi.org/10.2826/72202

Escobar, A. (2018). Designs for the Pluriverse: Radical Interdependence, Autonomy, and the Making of Worlds. Duke University Press. https://doi.org/10.1215/9780822371816

European Defence Agency. (2017). Successful test flight for EDA 3D-printing lab during deployment at EAATTC 17-3. Retrieved January 21, 2020, from https://eda.europa.eu/info-hub/press-centre/latest-news/2017/06/02/successfultest-flight-for-eda-3d-printing-lab-during-deployment-at-eaattc-17-3

European Defence Agency, E. (2012). European Armed Forces GO GREEN. https://doi.org/10.2836/13547

Fuller, T., \& Warren, L. (2006). Entrepreneurship as foresight: A complex social network perspective on organisational foresight. Futures, 38(8), 956-971. https://doi.org/10.1016/j.futures.2005.12.016

Gavetti. (2012). Toward a behavioral theory of strategy. Organization Science, 23(1), 267285. https://doi.org/DOI 10.1287/orsc.1110.0644

Godet, M. (2010). Future memories. Technological Forecasting and Social Change, 77(9), 
1457-1463. https://doi.org/10.1016/j.techfore.2010.06.008

Godet, Michel, \& Roubelat, F. (1996). Creating the Future: the use and misuse of scenarios. Long Range Planning, 29(2), 164-171.

Hampson, G. P. (2010). Futures of integral futures: An analysis of Richard Slaughter's analysis of Causal Layered Analysis. Futures, 42(2), 134-148. https://doi.org/10.1016/j.futures.2009.09.006

Hopkinson, N., Hague, R., \& Dickens, P. (2006). Rapid manufacturing: an industrial revolution for the digital age. John Wiley \& Sons.

Horowitz, M. C. (2014). Coming next in military tech. Bulletin of the Atomic Scientists, 70(1), 54-62. https://doi.org/10.1177/0096340213516743

Inayatullah, S. (1998). Macrohistory and futures studies. Futures, 30(5), 381-394. https://doi.org/10.1016/S0016-3287(98)00043-3

Inayatullah, S. (2004). The Causal Layered Analysis (CLA) Reader - Theory and Case Studies of an Integrative and Transformative Methodology. Tamkang University Press.

Inayatullah, S. (2010). Theory and practice in transformation: The disowned futures of Integral extension. $\quad$ Futures, 42(2), 103-109. https://doi.org/10.1016/j.futures.2009.09.002

Kanno, Y., \& Norton, B. (2003). Imagined Communities and Educational Possibilities: Introduction. Journal of Language, Identity \& Education, 2(4), 241-249. https://doi.org/10.1207/S15327701JLIE0204_1

Kietzmann, J., Pitt, L., \& Berthon, P. (2015). Disruptions, decisions, and destinations: Enter the age of 3-D printing and additive manufacturing. Business Horizons, 58(2), 209-215. https://doi.org/10.1016/j.bushor.2014.11.005

Kreutzmann, A., Koller, H., Andresen, F., \& Schulte, B. (2016). Communities of practice: Enabler of organizational knowledge creation? Proceedings of the European Conference on Knowledge Management, ECKM, 2016-Janua, 494-502.

Krogh, G. Von, Nonaka, I., \& Aben, M. (2001). Making the Most of Your Company ' s 
Knowledge : A Strategic Framework. Long Range Planning, 34, 421-439.

Lave, J., \& Wenger, E. (1991). Situated Learning: Legitimate Peripheral Participation. Cambridge: Cambridge University Press.

Lewis, S. L., \& Maslin, M. A. (2015). Defining the Anthropocene. Nature, 519(7542), 171180. https://doi.org/10.1038/nature14258

Li, L. C., Grimshaw, J. M., Nielsen, C., Judd, M., Coyte, P. C., \& Graham, I. D. (2009). Evolution of Wenger's concept of community of practice. Implementation Science, 4(1), 1-8. https://doi.org/10.1186/1748-5908-4-11

Liedtka, J. (1999). Linking competitive advantage with communities of practice. Journal of Management Inquiry, 8(1), 5-16.

Lindkvist, L. (2005). Knowledge Communities and Knowledge Collectivities: A Typology of Knowledge Work in Groups*. Journal of Management Studies, 42(6), 1189-1210. https://doi.org/10.1111/j.1467-6486.2005.00538.x

Maturana, H., \& Varela, F. J. (1994). El árbol del conocimiento: las bases biológicas del entendimiento humano. Colección Fuera de serie. Santiago de Chile: Editorial Universitaria.

McManus, S. (2016). From Military Green to Mali: how the European Defence Agency meets energy challenges. Retrieved May 27, 2019, from http://www.engineersjournal.ie/2016/05/17/military-green-european-defenceagency/

Metal AM. (2013). Additive Manufacturing Study Shows Cuts in Material Consumption and Reduced CO2 Emissions. Retrieved May 27, 2019, from https://www.metalam.com/additive-manufacturing-study-shows-cuts-in-material-consumption-andreduced- $\mathrm{CO}_{2}$-emissions/

Miller, C. A., O'Leary, J., Graffy, E., Stechel, E. B., \& Dirks, G. (2015). Narrative futures and the governance of energy transitions. Futures, 70(2014), 65-74. https://doi.org/10.1016/j.futures.2014.12.001 
Milojević, I., \& Inayatullah, S. (2015). Narrative foresight. Futures, 73, 151-162. https://doi.org/10.1016/j.futures.2015.08.007

Obydenkova, S., Anzalone, N. C., \& Pearce, J. M. (2018). Prospects of applying 3-D printing to economics of remote communities. Journal of Enterprising Communities: People and Places in the Global Economy, 12(4), 488-509. https://doi.org/10.1108/JEC-082016-0029

Orlikowski, W. J. (2000). Using Technology and Constituting Structures: A Practice Lens for Studying Technology in Organizations. Organization Science, 11(4), 404-428. https://doi.org/10.1287/orsc.11.4.404.14600

Pérez-Lombard, L., Ortiz, J., \& Pout, C. (2008). A review on buildings energy consumption information. Energy and Buildings, 40(3), 394-398. https://doi.org/10.1016/j.enbuild.2007.03.007

Peter, M. K., \& Jarratt, D. G. (2015). The practice of foresight in long-term planning. Technological Forecasting and Social Change, 101, 49-61. https://doi.org/10.1016/j.techfore.2013.12.004

Pór, G., \& Bekkum, E. Van. (2004). Liberating the Innovation Value of Communities of Practice. Knowledge Economics: Emerging Principles, Practices and Policies.

Pyrko, I., Dörfler, V., \& Eden, C. (2019). Communities of practice in landscapes of practice. Management Learning, 135050761986085. https://doi.org/10.1177/1350507619860854

Ramos, J. (2017). Cosmo-localization and leadership for the future. Journal of Futures Studies, 21(4), 65-84. https://doi.org/10.6531/JFS.2017.21(4).A65

Raven, P. G., \& Elahi, S. (2015). The New Narrative: Applying narratology to the shaping of futures outputs. Futures, 74, 49-61. https://doi.org/10.1016/j.futures.2015.09.003

Rayna, T., Striukova, L., \& Darlington, J. (2015). Co-creation and user innovation: The role of online 3D printing platforms. Journal of Engineering and Technology Management, 37, 90-102. https://doi.org/10.1016/j.jengtecman.2015.07.002 
Richardson, J. G., \& Erdelen, W. R. (2018). The Anthropocene: age of complexity, foresight and innovation? Foresight, 20(5), 571-582. https://doi.org/10.1108/FS-09-2018-100

Rodríguez Soria, B. (2017). Estudio sobre eficiencia energética en la base española en Líbano. Armas y Cuerpos, 136, 10-15. https://doi.org/ISSN-e 2445-0359

Ross, M. S. F. (2010). Innovation strategies for generic drug companies: moving into supergenerics. IDrugs : The Investigational Drugs Journal, 13(4), 243-247. Retrieved from http://www.ncbi.nlm.nih.gov/pubmed/20373253

Roubelat, F., Brassett, J., McAllum, M., Hoffmann, J., \& Kera, D. (2015). Probing ephemeral futures: Scenarios as fashion design. Futures, 74, 27-36. https://doi.org/10.1016/j.futures.2015.05.004

Sandler, T. (2004). Global Collective Action. Cambridge University Press. https://doi.org/10.1017/СBO9780511617119

Schacter, D. L., Addis, D. R., \& Buckner, R. L. (2007). Remembering the past to imagine the future: The prospective brain. Nature Reviews Neuroscience, 8(9), 657-661. https://doi.org/10.1038/nrn2213

Schulte, B., Andresen, F., \& Koller, H. (2020). Exploring the Embeddedness of an Informal Community of Practice Within a Formal Organizational Context: A Case Study in the German Military. Journal of Leadership \& Organizational Studies, 27(2), 153-179. https://doi.org/10.1177/1548051819833382

Spanish Ministry of Defence. (2017). Jornada Tecnológica. Impacto de la Fabricación Aditiva en Defensa - Presentaciones. Retrieved January 21, 2020, from http://tecnologiaeinnovacion.defensa.gob.es/eses/Contenido/Paginas/detallepublicacion.aspx?publicacionID =215

Steffen, W., Persson, Å., Deutsch, L., Zalasiewicz, J., Williams, M., Richardson, K., ... Svedin, U. (2011). The anthropocene: From global change to planetary stewardship. Ambio, 40(7), 739-761. https://doi.org/10.1007/s13280-011-0185-x

Stevenson, T. (2002). Communities of tomorrow. Futures, 34(8), 735-744. https://doi.org/10.1016/S0016-3287(02)00017-4 
Sydow, J. (2017). Temporary Organizing - The End of Organizations as We Know Them? Rutgers Business Review, 2(2), 199-204. Retrieved from https://docs.wixstatic.com/ugd/ddcf9a_451a024005a24750881a6e8d5781977b.pdf

Szpunar, K. K., Spreng, R. N., \& Schacter, D. L. (2014). A taxonomy of prospection: Introducing an organizational framework for future-oriented cognition. Proceedings of the National Academy of Sciences of the United States of America, 111(52), 1841418421. https://doi.org/10.1073/pnas.1417144111

Vicente-Oliva, S., Martínez-Sánchez, Á., \& Berges-Muro, L. (2016). Enhancing the outcomes in R\&D collaborative projects: an empirical analysis of the Middle Ebro Valley in Spain. International Journal of Innovation Management, 20(07), 1650061. https://doi.org/10.1142/S1363919616500614

von Hippel, E. (2015). Foreword: Progress in research on user innovation. Journal of Engineering and Technology Management, 37, 1-2. https://doi.org/10.1016/j.jengtecman.2015.09.002

Walker, B., Barrett, S., Polasky, S., Galaz, V., Folke, C., Engstrom, G., ... de Zeeuw, A. (2009). Looming Global-Scale Failures and Missing Institutions. Science, 325(5946), 13451346. https://doi.org/10.1126/science.1175325

Warner, K. S. R., \& Wäger, M. (2019). Building dynamic capabilities for digital transformation: An ongoing process of strategic renewal. Long Range Planning, 52(3), 326-349. https://doi.org/10.1016/j.Irp.2018.12.001

Wenger, E., \& Snyder, W. (2000). Communities of practice: The organizational frontier. Harvard Business Review, 78(1), 139-146.

Wenger, Etienne. (1998). Communities of Pactice: Learning, Menaing, and Identity. New York: Cambridge University Press.

Wilson, K., \& Doz, Y. L. (2011). Agile Innovation: A Footprint Balancing Distance and Immersion. California Management Review, 53(2), 6-26. https://doi.org/10.1525/cmr.2011.53.2.6

Yang, S. (2009). Using Blogs To Enhance Critical Reflection and Community of Practice 2.Pdf. 
Educational Technology \& Society, 12(2), 11-21.

Zhai, Y., Lados, D. A., \& LaGoy, J. L. (2014). Additive Manufacturing: Making Imagination the Major Limitation. JOM, 66(5), 808-816. https://doi.org/10.1007/s11837-014-0886-2 